\section{ALKOHOL KAO KRIMINOGENI ČIMBENIK KOD UBOJSTVA I POKUŠAJA UBOJSTVA}

\section{SAŽETAK}

Cilj ovog istraživanja bio je proučavanje i spoznavanje obilježja kaznenog djela ubojstva s obzirom na psihofizičko stanje, ali i karakteristike samih počinitelja. Istraživane su osobitosti počinitelja s obzirom na njihovo psihofizičko stanje pod vidom varijabli sociodemografskih, psihosocijalnih obilježja te obilježja kaznenog djela. Analizirani su pojmovi alkoholizma, akutne intoksikacije alkoholom i ubojstva. Istraživanje je provedeno na podacima o počiniteljima kaznenog djela ubojstva $i$ pokušaja ubojstva u Republici Hrvatskoj, vještačenim u Zavodu za forenzičnu psihijatriju NPB Dr. Ivan Barbot u Popovači. Rezultati istraživanja pokazuju specifičnosti tri ispitivane skupine (počinitelji kaznenog djela ubojstva koji su djelo počinili u akutno opitom stanju/stanju alkoholne intoksikacije, počinitelji s dijagnozom alkoholizma te počinitelji koji su djelo počinili u trijeznom

'Mateja Draganić, magistra socijalnog rada, e-mail: mateja.draganic@ hotmail.com

2 Doc.dr.sc.Dražen Kovačević, kliničkipsiholog, e-mail:drazen.kovacevic12@ gmail.com

${ }^{3}$ Izv. prof. dr. sc. Lana Mužinić, specijalistica psihijatrije, e-mail:lana.muzinic@inet.hr

${ }^{4}$ Nika Sušac, psihologinja, e-mail:nika.susac@gmail.com
Stručni rad

Primljeno: kolovoz, 2014.

Prihvaćeno: listopad, 2016.

UDK 343.61: 613.816

DOI 10.3935/ljsr.v23i2.35

Mateja Draganić

Dražen Kovačević ${ }^{2}$

Neuropsihijatrijska bolnica dr.

Ivan Barbot

Zavod za forenzičnu psihijatriju

Sveučilišni studijski centar za

forenzične znanosti

Sveučilište u Splitu

Lana Mužinićs

Klinička bolnica Dubrava

Klinika za psihijatriju

Nika Sušac ${ }^{4}$

Sveučilište u Zagrebu

Pravni fakultet

Studijski centar socijalnog rada

Ključne riječi:

alkohol, alkoholizam, ubojstvo. 
Ljetopis socijalnog rada 2016., 23 (2), 299-323 str.

stanju), posebice po pitanju varijabli koje se odnose na dob, bračni status, socioekonomski status, ranije činjenje kaznenih djela te broj prethodnih hospitalizacija. Iz rada proizlazi da je poznavanje i razumijevanje navedene problematike važno za djelovanje struke socijalnog rada, što može biti od pomoći u svakodnevnom radu, kako u prevenciji, tako i u radu s počiniteljima ubojstva $i$ njihovim obiteljima.

\section{UVOD}

Prekomjerna konzumacija alkoholnih pića ozbiljan je društveni i zdravstveni problem. Brojna su istraživanja svoje područje interesa usmjerila prema izučavanju utjecaja alkohola na organizam i ponašanje čovjeka. No, društvo na konzumaciju alkoholnih pića ne gleda kao na jedan od vodećih problema u svijetu, iako on može dovesti do smrti - kako osobe koja prekomjerno konzumira alkoholna pića i time razvija bolest ovisnosti, tako i osobe koja spletom okolnosti može postati žrtvom nasilničkog sukoba s alkoholiziranom osobom. Alkohol uz sebe veže poremećaje koji se dijele u dvije skupine - poremećaji uporabe alkohola, u koje ulaze ovisnost o alkoholu, odnosno alkoholizam, i zlouporaba alkohola, te poremećaji prouzročeni alkoholom, poput alkoholne intoksikacije/akutnog opitog stanja, alkoholnog apstinencijskog sindroma, alkoholnog intoksikacijskog i apstinencijskog delirija (Žarković Palijan, 2004.). Kako bi se primjerenije pristupilo svakom pojedinom problemu, nužno je razlikovati akutnu intoksikaciju i alkoholizam, s obzirom da svaka od imenovanih pojava ima i određene posljedice. Prema MKB-10 Klasifikaciji mentalnih poremećaja i poremećaja ponašanja (Svjetska zdravstvena organizacija, 1999.), akutna intoksikacija je prolazno stanje koje je posljedica uzimanja alkohola, a rezultira smetnjama svijesti, kognicije, percepcije, afekta, ponašanja ili drugih psiholoških funkcija ili reakcija. Prema istoj Klasifikaciji, sindrom ovisnosti o alkoholu je skupina pojava ponašanja, kognicija i fizioloških promjena koje se razvijaju nakon ponavljane uporabe alkohola i redovito uključuju jaku žudnju za uzimanjem te poteškoće u kontroli njezinog uzimanja. Ustrajući na uporabi alkohola unatoč štetnim posljedicama, pojedinac mnogo veću važnost pridaje uporabi alkohola, nego ostalim aktivnostima i obvezama, uz povećanje tolerancije i povremene tjelesne znakove apstinencije. Koludrović (2010.) akutno opito stanje definira kao prolazno psihofizičko stanje u koje se može dovesti svaki čovjek konzumirajući alkohol. Jednostavnije rečeno, riječ je o običnom pijanstvu, koje nestaje iščezavanjem alkohola iz tijela, uz potpuni oporavak. »Društvena potrošnja alkoholnih pića prelazi pojavom gubitka mogućnosti kontrole u bolest alkoholizma, a obilježava ju ovisnost o alkoholu, prestanak porasta tolerancije i različiti simptomi zdravstvenog 
i socijalnog oštećenja« (Žarković Palijan, 2004.: 16). Do danas se ne nalazi potpuna i jednostavna definicija alkoholizma, kao ni njena klasifikacija. No, sa sigurnošću se može reći kako je, za razliku od akutnog opitog stanja, riječ o bolesti. Žarković Palijan (2004.) navodi definiciju alkoholizma Hudolina, koji je istu modificirao iz, kako se navodi, praktičnih razloga. Hudolin pod pojmom »alkoholičar« smatra čovjeka koji je dugotrajnim konzumiranjem alkoholnih pića postao ovisan o alkoholu (psihički i/ili fizički) te su se zbog toga razvila zdravstvena (psihička/fizička) oštećenja i socijalne poteškoće. Smatrao je kako spomenuti simptomi moraju biti utvrđeni klasičnim medicinskim i socijalnim dijagnostičkim postupcima, a ne smiju se samo pretpostavljati i na temelju anamnestičkih podataka o prekomjernom konzumiranju alkoholnih pića zaključivati da bolesnik boluje od alkoholizma.

Glavni učinak alkohola je na mozak, ovisno o količini unesenog alkohola. Većina psihoanalitičara smatra kako je uzrok alkoholizma, između ostalog, mnoštvo specifičnih neuspjeha u emocionalnom razvoju i stjecaj obiteljskih okolnosti, poput obiteljske povijesti alkoholizma, koja je prisutna u većini slučajeva (Žarković Palijan, 2004.). Od mnogobrojnih problema koje uzrokuje konzumacija alkohola (amnezija, promjene ličnosti), posebno se ističu oni od kriminogenog značaja. Točnije, oni problemi koje alkohol uzrokuje u smjeru manifestiranja agresije, nasilja usmjerenog prema drugim ljudima. Odnosi između alkohola i agresivnih zločina/ kaznenih djela su jaki, isprepleteni i raznoliki. Alkohol se najčešće spominje kao provocirajući faktor, to jest faktor koji potiče agresivno ponašanje. »Alkoholizirana osoba s agresivnim ponašanjem predstavlja veliku opasnost za sebe i svoju okolinu« (Kovačević, 2008.: 67). Postoje brojne teorije koje pokušavaju objasniti agresiju i agresivno ponašanje, ali i one koje traže i objašnjavaju vezu između alkohola i agresije. Jedna od značajnijih je bihevioristička teorija koja agresiju u pijanstvu povezuje sa stanjem ovisnog učenja. Osoba informaciju naučenu u pijanstvu i doživljenu emociju koju veže uz nju ne može prenijeti u trijezno stanje. Kada je osoba dovedena u sličnu situaciju, prisjeća se prošlih agresivnih ponašanja, vezanih uz emocije koje su se u ključnoj situaciji probudile, te ponavlja prošla ponašanja. Također, poznata je i činjenica kako je agresivnost u trijeznom stanju praćena osjećajem krivnje. U tim slučajevima osobe posežu za alkoholnim pićima kako bi se oslobodile nelagodnih, neželjenih osjećaja, te se uz to oslobađa agresija (Koludrović, 2010.). Žarković Palijan, pozivajući se na Pinatela (1959., prema Žarković Palijan, 2004.), navodi kako stanje pijanstva smanjuje sposobnost upravljanja vlastitim postupcima. Alkohol djeluje kao podražajno sredstvo, potaknuto ljubomorom, osjetljivošću, uvrijeđenošću, obiteljskom mržnjom, pa čak i starim, u svijesti zadržanim povredama te se time agresivnost oslobađa i povećava. Općenito govoreći, u okviru agresivnog/nasilničkog ponašanja nalaze se nasilnički delikti različite prirode i intenziteta - od uvreda do ubojstva, od zlostavljanja do teških akata terora 
(Singer, 1995., prema Džaja-Hajduk, 2003.). Podaci WHO-a (2002.) ukazuju da je tijekom 2000. godine više od milijun ljudi podleglo posljedicama određenog oblika nasilja. Isto tako, nasilje je vodeći uzrok smrti svjetske populacije u dobi od 15 do 44 godine.

Potrošnja alkohola, posebice u velikim količinama, znatan je čimbenik rizika za nasilje. U prilog tome govore i brojna istraživanja koja dokazuju snažnu povezanost između konzumacije alkohola i nasilničkog ponašanja (Bushman i Cooper, 1990.; Fagan, 1990.; Dundović, 2008.). Od ukupno 30\% uvjetnih zatvorskih presuda, prema godišnjem izvješću EMCDDA, ${ }^{4}$ čak $70 \%$ povezano je s nasiljem u alkoholiziranom stanju, te je 44\% svih nasilnih incidenata vezano uz zloupotrebu alkohola (Kovačević, 2008.). »Kod alkoholičara se razlikuju dva oblika agresivnog ponašanja: a) agresija kod akutne intoksikacije i b) agresija kod kroničnog alkoholizma« (Kovačević, 2008.: 67). Alkohol, u slučaju intoksikacije, prvenstveno djeluje na mozak čovjeka te utječe na promjenu ponašanja. Ometa kapacitete osobe za obradu informacija, pa se samim time i povećava mogućnost nesporazuma u međuljudskim odnosima. Navedeno se objašnjava činjenicom kako konzumacija alkohola dovodi do težeg prihvaćanja perspektive, odnosno mišljenja/stavova drugih ljudi, i težeg rješavanja problema, te do koncepta »alkoholne kratkovidnosti« u kojem se osoba usredotočuje samo na neposrednu situaciju, s ograničenim obaziranjem na posljedice svojih postupaka. Iznad svega, konzumente čini više impulzivnima, emocionalnima i introspektivnima. Takvi nasilnici također se opisuju kao nesigurni, ljubomorni, emocionalno ovisni i uhvaćeni u zamke stereotipnih uloga koje im uvjetuje njihov spol (Dundović, 2008.). Alkoholizam se, s druge strane, kao jedan od faktora nasilničkog kriminaliteta susreće kod svih kaznenih djela, odnosno jednostavnije rečeno, ne postoji kazneno djelo kod kojeg alkoholizam kao faktor ne bi mogao biti prisutan na neki način (Žarković Palijan, 2004.). Alkoholizam je povezan s drugim psihološkim faktorima, različitim od akutnog (običnog) pijanstva, koji su sami po sebi povezani s nasiljem. Riječ je o asocijalnoj ličnosti, depresiji, anksioznom poremećaju, poremećaju ličnosti, poremećaju u ponašanju i slično. Prema Deardenu i Paynu (2009.), svake godine oko 4,5\% Australaca (775 000 osoba starijih od 14 godina) navodi kako su bili fizički zlostavljani od strane nekoga za koga smatraju da je bio pod utjecajem alkohola. Također, $25 \%$ navodi kako je od istih osoba zlostavljano i verbalno (AlHW, 2008., prema Dearden i Payne, 2009.). Nadalje, podaci iz Australskog instituta za kriminologiju pokazuju kako je velik broj ljudi uhićen od strane policije za počinjenje određene vrste nasilničkog delikta konzumirao alkohol u razdoblju od 48 sati prije uhićenja. Rezultati intervjua sa zatvorenicima koji su zatvoreni zbog nasilničkih delikata pokazuju kako je 34\% zatvorenika

${ }^{4}$ EMCDDA - European Monitoring Centre for Drugs and Drug Addiction. 
u trenutku počinjenja najtežeg djela bilo ovisno o alkoholu, dok je nešto manje od polovice, oko 44\%, bilo akutno opijeno u trenutku počinjenja najtežeg kaznenog djela (Makkai i Payne, 2003., prema Dearden i Payne, 2009.). Od kaznenih djela s elementima nasilja, zloupotrebi alkohola pripisuje se $70 \%$ svih ubodnih ranjavanja, $70 \%$ teškog premlaćivanja, $50 \%$ slučajeva nasilja u obitelji te 60 do $70 \%$ ubojstava (Flanagan i Fisher, 2008.).

Posebno je nužno osvrnuti se na najdrastičniji primjer nasilja - ubojstvo. Ubojstvo se smatra jednim od najtežih i najopasnijih oblika kriminaliteta zbog toga što je riječ o uništavanju ljudskog bića, to jest uzrokovanju smrti čovjeka. Odnosno, riječ je o povredi jednog od najvažnijih i najosnovnijih ljudskih prava koje štite brojni međunarodni, ali i nacionalni dokumenti. Navedeno kazneno djelo ima destruktivan učinak jer, osim uništenja ljudskog života, ima i negativan učinak na osobe koje nisu sudjelovale u samom događaju - na obitelj žrtve i obitelj počinitelja (Kovačević, 2008.). Mužinić Masle i Goreta (2000.) tvrde kako je odnos alkoholiziranih stanja i delikata protiv života i tijela nedvosmislen te kako su ti delikti u oko polovini slučajeva udruženi s alkoholiziranim stanjem. Vrlo je važno napomenuti kako pri vještačenju počinitelja kaznenog djela ubojstva i pokušaja ubojstva koja su direktno povezana s intoksikacijom alkoholom, forenzički psihijatri i psiholozi nalaze više psihijatrijskih komorbiditeta. Najčešće su prisutni poremećaj ličnosti, poremećaj afekta, ADHD, paranoidna psihoza te shizofrenija (Kaminer i Bukstein, 2008.). Posebno rizična grupa počinitelja teškog ubojstva su osobe muškog spola s dijagnozom shizofrenije koje zlorabe alkohol (Flanagan i Fisher, 2008.). Konzumacija alkohola doprinosi počinjenju kaznenog djela ubojstva na mnogobrojne načine - svađe i tučnjave u alkoholiziranom stanju, uzimanje najbližeg predmeta za izvršenje djela, alkohol kao dezinhibirajući faktor, poremećaj svijesti i drugih psihičkih funkcija (Mužinić Masle i Goreta, 2000.). Veliku ulogu imaju i razni situacijski čimbenici. Situacijske čimbenike može se povezati s najčešćim motivima koji se javljaju kod počinjenja kaznenog djela ubojstva kod osoba pod utjecajem alkohola, pri čemu se ističu ljubomora, bračne razmirice i osveta. Povećana ljubomora je česta kod osoba koje prekomjerno piju. Tijekom trajanja alkoholne bolesti, odnosno alkoholizma, osobe razvijaju oblik bolesti koja se naziva alkoholna paranoja - stanje kada ljubomora poprimi karakter sumanutih ideja. U naglašenom afektivnom stanju, odnosno pod utjecajem paranoidnih ideja, na primjer, u vezi nevjere supruge, a pod utjecajem alkohola, osobe se često odlučuju na ubojstvo. Alkohol na organizam čovjeka i njegovo ponašanje ima višestruko djelovanje, a najvažnije od svega je to što smanjuje strah stvarajući osjećaj lažne hrabrosti te se osobe sklone prekomjernom konzumiranju alkoholnih pića odlučuju na kaznena djela, poput ubojstva, a koja u trijeznom stanju i pri punoj svijesti, vjerojatno nikada ne bi počinili. 


\section{CILJ I PROBLEMI ISTRAŽIVANJA}

Glavni cilj ovog istraživanja je ispitati obilježja kaznenog djela ubojstva i pokušaja ubojstva muških počinitelja vještačenih u Zavodu za forenzičnu psihijatriju Neuropsihijatrijske bolnice Dr. Ivan Barbot u Popovači, s posebnim osvrtom na psihofizičko stanje počinitelja u trenutku počinjenja kaznenog djela.

Sukladno postavljenom cilju problemi istraživanja bili su:

Ispitati obilježja počinitelja ubojstva s obzirom na psihofizičko stanje u trenutku počinjenja kaznenog djela prema sociodemografskim i psihosocijalnim varijablama.

Ispitati obilježja počinitelja ubojstva s obzirom na psihofizičko stanje u trenutku počinjenja kaznenog djela prema varijablama kaznenog djela.

\section{METODA}

\section{Uzorak}

Uzorak je uključivao 100 počinitelja kaznenog djela ubojstva u Republici Hrvatskoj u razdoblju od 1991. do 2014. godine (42 počinitelja ubojstva u pokušaju) kojima je bilo određeno vještačenje. $U$ istraživanje su uključene samo osobe muškog spola, zbog nemogućnosti izjednačavanja uzorka po spolu, budući da je mali udio žena evidentiran među počiniteljima ubojstava i pokušaja ubojstva u Republici Hrvatskoj (15 žena od ukupno 143 počinitelja 2012. godine), ali i zbog specifičnosti kaznenog djela ubojstva koja čine žene (čedomorstvo). Prosječna dob počinitelja iznosi 41 godinu ( $M=40,55 ; S D=15,307)$. U trenutku počinjenja kaznenog djela (eng. tempore criminis) bilo je 50 trijeznih i 50 alkoholiziranih počinitelja (20 ovisnika o alkoholu i 30 akutno intoksiciranih).

\section{Mjerni instrument i postupak}

U svrhu ovog istraživanja korištena je posebno konstruirana provjerna lista, koja se sastoji od tri dijela: sociodemografskih obilježja, psihosocijalnih obilježja te obilježja kaznenog djela. Svaki od tih dijelova uključivao je niz varijabli s unaprijed određenim kategorijama odgovora. Uz pitanja koja su bila specifično sastavljena za provedeno istraživanje, radi moguće komparacije s drugim istraživanjima, sadržavala je i pitanja upotrijebljena u ranijim istraživanjima (npr. Kozarić-Kovačić, 1996.; Nađ, 2001.; Dundović, 2005.; Kovačević, 2008.). Za svakog počinitelja ispunjavala se zasebna provjerna lista na temelju podataka sadržanih u sudsko-psihija-

\section{4 članci}


trijskoj ekspertizi. Autori rada odabrali su iz dostupne dokumentacije slučajeve koji su prema određenim obilježjima (vrijeme počinjenja djela, spol i kazneno djelo) odgovarali planiranom uzorku. Zatim su na temelju informacija iz sudsko-psihijatrijske ekspertize u SPSS program unošeni odgovarajući podaci za svakog počinitelja. lako su provoditeljima istraživanja bili dostupni i osobni podaci počinitelja navedeni u dokumentaciji, oni nigdje nisu evidentirani u svrhu ovog istraživanja, odnosno svi su rezultati bili anonimizirani.

S obzirom da je glavni cilj istraživanja odrediti obilježja počinitelja kaznenog djela ubojstva s obzirom na psihofizičko stanje počinitelja, provedena je deskriptivna analiza podataka na razini cijelog uzorka te zasebno za subuzorke formirane s obzirom na psihofizičko stanje počinitelja u trenutku počinjenja kaznenog djela.

\section{REZULTATI ISTRAŽIVANJA}

U uzorku najmlađi počinitelj ima 15 godina, a najstariji 78 godina. Većinom su u odrasloj i zreloj dobi $(M=40,55 ; S D=15,307)$. Prosječna dob počinitelja ovisnika o alkoholu je 50 ( $M=50,35 ; S D=10,499)$, počinitelja koji su djelo počinili u trijeznom stanju 37 ( $M=37,06 ; S D=15,057)$, a počinitelja koji su djelo počinili u akutnom opitom stanju 40 godina ( $M=39,79 ; S D=16,048)$.

U nastavku će biti prikazani dobiveni rezultati na cijelom uzorku te po pojedinim skupinama počinitelja s obzirom na psihofizičko stanje u trenutku počinjenja kaznenog djela. Treba naglasiti da se radi o prikazu deskriptivnih podataka jer su, zbog kategorijalne prirode korištenih varijabli, počinitelji podijeljeni u podskupine te je njihov broj u pojedinim ćelijama bio premalen za provedbu hi-kvadrat testa, kojim bi se provjerila značajnost razlika među njima. Unatoč tome, na temelju prikazanih postotaka moguće je uočiti neke trendove i specifičnosti svake od navedenih skupina. Stoga su svi rezultati prikazani za cijeli uzorak, dok su po skupinama prikazani samo rezultati na varijablama gdje su uočeni takvi različiti trendovi.

Većina počinitelja nije u partnerskom odnosu (66\%), odnosno nisu sklapali bračnu zajednicu, udovci su ili razvedeni (Tablica 1.). Među počiniteljima s dijagnozom alkoholizma najveći je udio onih u partnerskim zajednicama (50\%), dok su počinitelji u trijeznom stanju najčešće bez partnerskog odnosa (76\%), a najčešće nikada nisu ni sklapali nikakvu bračnu zajednicu (62\%). 
Ljetopis socijalnog rada 2016., 23 (2), 299-323 str.

Tablica 1. Bračni status počinitelja kaznenih djela s obzirom na psihofizičko stanje u trenutku počinjenja kaznenog djela $(N=100)$

\begin{tabular}{lcccc}
\hline & $\begin{array}{c}\text { Trijezno stanje } \\
\mathbf{N}(\%)\end{array}$ & $\begin{array}{c}\text { Akutno opito } \\
\text { stanje N (\%) }\end{array}$ & $\begin{array}{c}\text { Dijagnoza alko- } \\
\text { holizma N (\%) }\end{array}$ & $\begin{array}{c}\text { Cijeli uzorak } \\
\text { (N = \%) }\end{array}$ \\
\hline Oženjen & $10(20,0)$ & $8(26,7)$ & $6(30,0)$ & 24 \\
\hline Neoženjen & $31(62,0)$ & $13(43,3)$ & $5(25,0)$ & 49 \\
\hline Razveden & $6(12,0)$ & $4(13,3)$ & $5(25,0)$ & 15 \\
\hline Udovac & $1(2,0)$ & $1(3,3)$ & - & 2 \\
\hline $\begin{array}{l}\text { U vanbračnoj } \\
\text { zajednici }\end{array}$ & $2(4,0)$ & $4(13,3)$ & $4(20,0)$ & 10 \\
\hline Ukupno & $50(100,0)$ & $30(100,0)$ & $20(100,0)$ & 100 \\
\hline
\end{tabular}

Najviše počinitelja ima završeno srednjoškolsko obrazovanje (44\%, Tablica 2.) i prosječnog su socioekonomskog statusa (54\%). Počinitelji s dijagnozom alkoholizma imaju većinom nepovoljan socioekonomski status (60\%), dok počinitelji ubojstva koji su djelo počinili akutno intoksicirani i trijezni počinitelji uglavnom (56,7\%; 58\%) imaju osrednji socioekonomski status (Tablica 3.).

Tablica 2. Razina obrazovanja i radni status počinitelja kaznenih djela $(\mathrm{N}=100)$

\begin{tabular}{lclc}
\hline \multicolumn{2}{c}{ Razina obrazovanja (N = \%) } & \multicolumn{2}{c}{ Radni status N (N = \%) } \\
\hline Nezavršena OŠ & 19 & Zaposlen & 32 \\
\hline Završena OŠ & 34 & Nezaposlen & 43 \\
\hline SSS & 44 & Školuje se & 3 \\
\hline VŠS, VSS & 1 & U mirovini & 19 \\
\hline MAG, DR & - & Nema podataka & 3 \\
\hline Nema podataka & 2 & Ukupno & 100 \\
\hline Ukupno & 100 & & \\
\hline
\end{tabular}

Tablica 3. Socioekonomski status počinitelja kaznenih djela s obzirom na psihofizičko stanje u trenutku počinjenja kaznenog djela $(N=100)$

\begin{tabular}{lcccc}
\hline & $\begin{array}{c}\text { Trijezno stanje } \\
\mathbf{N}(\%)\end{array}$ & $\begin{array}{c}\text { Akutno opito } \\
\text { stanje N (\%) }\end{array}$ & $\begin{array}{c}\text { Dijagnoza } \\
\text { alkoholizma } \\
\mathbf{N}(\%)\end{array}$ & $\begin{array}{c}\text { Cijeli uzorak (N } \\
=\%)\end{array}$ \\
\hline Odličan & - & - & - & - \\
\hline Vrlo dobar & $9(18,0)$ & $5(16,7)$ & - & 14 \\
\hline Osrednji & $29(58,0)$ & $17(56,7)$ & $8(40,0)$ & 54 \\
\hline Loš & $10(20,0)$ & $6(20,0)$ & $12(60,0)$ & 28 \\
\hline Nema podataka & $2(4,0)$ & $2(6,7)$ & - & 4 \\
\hline Ukupno & $50(100,0)$ & $30(100,0)$ & $20(100,0)$ & 100 \\
\hline
\end{tabular}


Počinitelji u uzorku podjednako često žive sa svojim roditeljima (34\%) ili sa svojim obiteljima (31\%). Sa svojim obiteljima živi 50\% počinitelja s dijagnozom alkoholizma i $40 \%$ počinitelja u akutno opitom stanju. Polovina počinitelja $(46,0 \%) \mathrm{u}$ trijeznom stanju živi u kućanstvu sa svojim roditeljima (Tablica 4.).

Tablica 4. Udio počinitelja kaznenih djela s obzirom na psihofizičko stanje u trenutku počinjenja kaznenog djela prema tome $s$ kim žive $(N=100)$

\begin{tabular}{lcccc}
\hline & $\begin{array}{c}\text { Trijezno stanje } \\
\text { N (\%) }\end{array}$ & $\begin{array}{c}\text { Akutno opito } \\
\text { stanje N (\%) }\end{array}$ & $\begin{array}{c}\text { Dijagnoza } \\
\text { alkoholizma } \\
\mathbf{N}(\%)\end{array}$ & $\begin{array}{c}\text { Cijeli uzorak } \\
\text { (N = \%) }\end{array}$ \\
\hline Sam & $11(22,0)$ & $5(16,7)$ & $4(20,0)$ & 20 \\
\hline S obitelji & $9(18,0)$ & $12(40,0)$ & $10(50,0)$ & 31 \\
\hline S roditeljima & $23(46,0)$ & $9(30,0)$ & $2(10,0)$ & 34 \\
\hline U instituciji & $4(8,0)$ & - & $1(5,0)$ & 5 \\
\hline S nekim drugim & $3(6,0)$ & $3(10,0)$ & $3(15,0)$ & 9 \\
\hline Nema podataka & - & $1(3,3)$ & - & 1 \\
\hline Ukupno & $50(100,0)$ & $30(100,0)$ & $20(100,0)$ & 100 \\
\hline
\end{tabular}

Velika većina počinitelja (81\%) živi u manjem gradu ili na selu (Tablica 5.). Većina osoba s dijagnozom alkoholizma živi na selu (60\%), dok je u druge dvije skupine najveći udio onih koji žive u manjem gradu (46,7\% u akutno opitom stanju te $44 \%$ trijeznih počinitelja).

Tablica 5. Veličina mjesta prebivališta počinitelja kaznenih djela s obzirom na psihofizičko stanje u trenutku počinjenja kaznenog djela $(N=100)$

\begin{tabular}{lcccc}
\hline & $\begin{array}{c}\text { Trijezno stanje } \\
\mathbf{N}(\%)\end{array}$ & $\begin{array}{c}\text { Akutno opito } \\
\text { stanje N (\%) }\end{array}$ & $\begin{array}{c}\text { Dijagnoza } \\
\text { alkoholizma } \\
\mathbf{N}(\%)\end{array}$ & $\begin{array}{c}\text { Cijeli uzorak } \\
\mathbf{( N = \% )}\end{array}$ \\
\hline Glavni grad & $3(6,0)$ & $2(6,7)$ & - & 5 \\
\hline Veliki grad & $10(20,0)$ & $2(6,7)$ & $1(5,0)$ & 13 \\
\hline Manji grad & $22(44,0)$ & $14(46,7)$ & $7(35,0)$ & 43 \\
\hline Selo & $15(30,0)$ & $11(36,7)$ & $12(60,0)$ & 38 \\
\hline Nema podataka & - & $1(3,3)$ & - & 1 \\
\hline Ukupno & $50(100,0)$ & $30(100,0)$ & $20(100,0)$ & 100 \\
\hline
\end{tabular}

Skoro polovina počinitelja odrastala je u narušenoj obiteljskoj sredini (Tablica 6.). Velika većina počinitelja ( $90 \%)$ bračna su djeca, a svaki peti (20\%) doživio je razvod roditelja (Tablica 7.). Skoro dvije trećine odrastalo (65\%) je uz oba roditelja. Smrt roditelja do punoljetnosti doživio je svaki 11. počinitelj kaznenog djela ubojstva. 
Tablica 6. Kvaliteta odnosa u primarnoj obitelji počinitelja kaznenih djela s obzirom na psihofizičko stanje u trenutku počinjenja kaznenog djela $(N=100)$

\begin{tabular}{lcccc}
\hline & $\begin{array}{c}\text { Trijezno stanje } \\
\mathbf{N}(\%)\end{array}$ & $\begin{array}{c}\text { Akutno opito } \\
\text { stanje N (\%) }\end{array}$ & $\begin{array}{c}\text { Dijagnoza } \\
\text { alkoholizma } \\
\mathbf{N}(\%)\end{array}$ & $\begin{array}{c}\text { Cijeli uzorak } \\
\text { (N = \%) }\end{array}$ \\
\hline Narušeni & $23(46,0)$ & $12(40,0)$ & $11(55,0)$ & 46 \\
\hline Dobri & $19(38,0)$ & $11(36,7)$ & $7(35,0)$ & 37 \\
\hline Vrlo dobri & $5(10,0)$ & $4(13,3)$ & - & 9 \\
\hline Nema podataka & $3(6,0)$ & $3(10,0)$ & $2(10,0)$ & 8 \\
\hline Ukupno & $50(100,0)$ & $30(100,0)$ & $20(100,0)$ & 100 \\
\hline
\end{tabular}

Tablica 7. Okolnosti odrastanja u primarnoj obitelji počinitelja kaznenih djela $(\mathrm{N}=100)$

\begin{tabular}{lclcllc}
\hline $\begin{array}{c}\text { Tijekom odrastanja počinitelj je } \\
\text { živio: }(\mathbf{N}=\text { \%) }\end{array}$ & Bračno dijete $\mathbf{( N = \% )}$ & \multicolumn{2}{c}{$\begin{array}{c}\text { Razvedeni roditelji } \\
\text { (N= \%) }\end{array}$} \\
\hline S oba roditelja & 65 & $\mathrm{Da}$ & 90 & $\mathrm{Da}$ & 20 \\
\hline S jednim roditeljem & 13 & $\mathrm{Ne}$ & 4 & $\mathrm{Ne}$ & 74 \\
\hline Jedan roditelj i maćeha/očuh & 6 & Nema podataka & 6 & Nema podataka & 6 \\
\hline Kod udomitelja & 2 & Ukupno & 100 & Ukupno & 100 \\
\hline Nema podataka & 4 & & & & \\
\hline Ukupno & 100 & & & \\
\hline
\end{tabular}

Podaci o ranom razvoju i iskustvima u obitelji većinom nisu dostupni za više od $50 \%$ počinitelja, zbog čega te podatke treba uzeti s posebnim oprezom (Tablice 8., 9. i 10.). Tijekom odrastanja preko polovine (51\%) počinitelja imalo je poteškoća tijekom školovanja, skoro trećina (30\%) zloupotrebljavala je alkoholna pića, a skoro četvrtina (23\%) imala je bjegove od kuće (Tablica 8.). Među počiniteljima ubojstva koji su djelo počinili trijezni najmanji je udio smetnji u ranom socijalnom razvoju i obrazovanju. Rana zloupotreba alkohola, još za vrijeme osnovnoškolskog obrazovanja, evidentirana je kod $40 \%$ počinitelja sa dijagnozom alkoholizma te kod $36,7 \%$ akutno opijenih počinitelja. 
Tablica 8. Smetnje u socijalnom razvoju i obrazovanju počinitelja kaznenih djela s obzirom na psihofizičko stanje u trenutku počinjenja kaznenog djela $(N=100)$

\begin{tabular}{|c|c|c|c|c|c|}
\hline & & $\begin{array}{c}\text { Trijezno } \\
\text { stanje N (\%) }\end{array}$ & $\begin{array}{c}\text { Akutno opito } \\
\text { stanje N (\%) }\end{array}$ & $\begin{array}{c}\text { Dijagnoza } \\
\text { alkoholizma } \\
\text { N (\%) } \\
\end{array}$ & $\begin{array}{c}\text { Cijeli } \\
\text { uzorak } \\
(\mathbf{N}=\%)\end{array}$ \\
\hline \multirow{4}{*}{$\begin{array}{l}\text { Problemi } \\
\text { tijekom } \\
\text { školovanja }\end{array}$} & $\mathrm{Da}$ & $24(48,0)$ & $15(50,0)$ & $12(60,0)$ & 51 \\
\hline & $\mathrm{Ne}$ & $17(34,0)$ & $4(13,3)$ & $4(20,0)$ & 25 \\
\hline & Nema podataka & $9(18,0)$ & $19(63,3)$ & $4(20,0)$ & 76 \\
\hline & Ukupno & $50(100,0)$ & $30(100,0)$ & $20(100,0)$ & 100 \\
\hline \multirow{4}{*}{$\begin{array}{l}\text { Bježanje od } \\
\text { kuće }\end{array}$} & $\mathrm{Da}$ & $11(22,0)$ & $8(26,7)$ & $4(20,0)$ & 23 \\
\hline & $\mathrm{Ne}$ & $19(38,0)$ & $5(16,7)$ & $4(20,0)$ & 28 \\
\hline & Nema podataka & $20(40,0)$ & $17(56,7)$ & $12(60,0)$ & 51 \\
\hline & Ukupno & $50(100,0)$ & $30(100,0)$ & $20(100,0)$ & 100 \\
\hline \multirow{4}{*}{$\begin{array}{l}\text { Zlouporaba } \\
\text { alkohola }\end{array}$} & $\mathrm{Da}$ & $11(22,0)$ & $11(36,7)$ & $8(40,0)$ & 30 \\
\hline & $\mathrm{Ne}$ & $18(36,0)$ & $4(13,3)$ & $1(5,0)$ & 23 \\
\hline & Nema podataka & $21(42,0)$ & $15(50,0)$ & $11(55,0)$ & 53 \\
\hline & Ukupno & $50(100,0)$ & $30(100,0)$ & $20(100,0)$ & 100 \\
\hline \multirow{4}{*}{$\begin{array}{l}\text { Druženje s } \\
\text { asocijalnim } \\
\text { osobama }\end{array}$} & $\mathrm{Da}$ & $12(24,0)$ & $5(16,7)$ & $1(5,0)$ & 18 \\
\hline & $\mathrm{Ne}$ & $18(36,0)$ & $6(20,0)$ & $2(10,0)$ & 26 \\
\hline & Nema podataka & $20(40,0)$ & $19(63,3)$ & $17(85,0)$ & 44 \\
\hline & Ukupno & $50(100,0)$ & $30(100,0)$ & $20(100,0)$ & 100 \\
\hline \multirow{4}{*}{$\begin{array}{l}\text { Maloljetnička } \\
\text { delinkvencija }\end{array}$} & $\mathrm{Da}$ & $8(16,0)$ & $6(20,0)$ & $1(5,0)$ & 15 \\
\hline & $\mathrm{Ne}$ & $18(36,0)$ & $6(20,0)$ & $2(10,0)$ & 26 \\
\hline & Nema podataka & $24(48,0)$ & $18(60,0)$ & $17(85,0)$ & 41 \\
\hline & Ukupno & $50(100,0)$ & $30(100,0)$ & $20(100,0)$ & 100 \\
\hline
\end{tabular}

Uz velik broj nedostatnih podataka, gotovo polovina počinitelja ima pozitivnu obiteljsku anamnezu alkoholizma, a najčešće je to otac. Uz oca alkoholičara odrastalo je $65 \%$ počinitelja ubojstva s dijagnozom alkoholizma, odnosno svakom petom (20\%) bila je i majka sklona prekomjernoj konzumaciji alkohola. Kod svih počinitelja kod kojih je bio prisutan alkoholizam majke oba su roditelja bila alkoholičari. Uz oca alkoholičara odrastalo je i 40\% akutno intoksiciranih počinitelja. 
Tablica 9. Alkoholizam u primarnoj obitelji počinitelja kaznenih djela s obzirom na psihofizičko stanje u trenutku počinjenja kaznenog djela $(N=100)$

\begin{tabular}{|c|c|c|c|c|c|}
\hline & & $\begin{array}{c}\text { Trijezno sta- } \\
\text { nje N (\%) }\end{array}$ & $\begin{array}{c}\text { Akutno opito } \\
\text { stanje N (\%) }\end{array}$ & $\begin{array}{c}\text { Dijagnoza } \\
\text { alkoholizma } \\
\text { N (\%) }\end{array}$ & $\begin{array}{l}\text { Cijeli uzorak } \\
\text { (N=\%) }\end{array}$ \\
\hline \multirow{4}{*}{ Majka } & $\mathrm{Da}$ & - & $2(6,7)$ & $4(20,0)$ & 6 \\
\hline & $\mathrm{Ne}$ & $18(36,0)$ & $11(36,7)$ & $8(40,0)$ & 37 \\
\hline & Nema podataka & $32(64,0)$ & $17(56,7)$ & $8(40,0)$ & 57 \\
\hline & Ukupno & $50(100,0)$ & $30(100,0)$ & $20(100,0)$ & 100 \\
\hline \multirow{4}{*}{ Otac } & $\mathrm{Da}$ & $9(18,0)$ & $12(40,0)$ & $13(65,0)$ & 34 \\
\hline & $\mathrm{Ne}$ & $9(18,0)$ & $3(10,0)$ & $1(5,0)$ & 13 \\
\hline & Nema podataka & $32(64,0)$ & $15(50,0)$ & $6(30,0)$ & 53 \\
\hline & Ukupno & $50(100,0)$ & $30(100,0)$ & $20(100,0)$ & 100 \\
\hline \multirow{4}{*}{$\begin{array}{l}\text { Netko } \\
\text { drugi }\end{array}$} & $\mathrm{Da}$ & $4(8,0)$ & $4(13,3)$ & $2(10,0)$ & 10 \\
\hline & $\mathrm{Ne}$ & $6(12,0)$ & $1(3,3)$ & $1(5,0)$ & 8 \\
\hline & Nema podataka & $40(80,0)$ & $25(83,3)$ & $17(85,0)$ & 82 \\
\hline & Ukupno & $50(100,0)$ & $30(100,0)$ & $20(100,0)$ & 100 \\
\hline
\end{tabular}

Podaci o nasilju u primarnoj obitelji nisu poznati da polovicu uzorka (Tablica 10.), dok je $40 \%$ počinitelja doživjelo nasilje, najčešće psihičko, fizičko i zanemarivanje.

Tablica 10. Nasilje prema počinitelju u primarnoj obitelji $(N=100)$

\begin{tabular}{lcccccc}
\hline & $\begin{array}{l}\text { Ukupno } \\
\text { (N = \%) }\end{array}$ & \multicolumn{5}{c}{ Oblik doživljenog nasilja (N = \%) } \\
\cline { 3 - 7 } & 40 & Psihičko & Fizičko & Financijsko & Spolno & Zanemarivanje \\
\hline $\mathrm{Da}$ & 10 & 10 & 11 & 13 & 13 & 12 \\
\hline $\mathrm{Ne}$ & 50 & 51 & 63 & 87 & 87 & 64 \\
\hline $\begin{array}{l}\text { Nema } \\
\text { podata- } \\
\text { ka }\end{array}$ & 50 & 100 & 100 & 100 & 100 & 100 \\
\hline Ukupno & 100 & 100 & & & & \\
\hline
\end{tabular}

Najzastupljenije intervencije $\mathrm{u}$ okviru sustava socijalne skrbi bile su u postupku razvoda braka (25\%), dok za ostale intervencije podaci većinom nisu poznati (Tablica 11.). Iz podataka koji jesu dostupni vidljivo je da su najviše zastupljeni izvidi u obitelj (23\%), intervencije povezane s invaliditetom korisnika (18\%) te materijalna pomoć obitelji (15\%). 
Tablica 11. Ranije počinjena kaznena djela i intervencije u okviru sustava socijalne skrbi u obitelji počinitelja $(\mathrm{N}=100)$

\begin{tabular}{|c|c|c|c|c|c|c|c|c|c|c|}
\hline & \multirow{2}{*}{$\begin{array}{c}\text { Ranije } \\
\text { počinjenje } \\
\text { kaznenog } \\
\text { djela ( } N=\%)\end{array}$} & \multirow{2}{*}{$\begin{array}{c}\text { Ranije počinjenje } \\
\text { ubojstva/ } \\
\text { pokušaja ubojstva } \\
(\mathrm{N}=\%)\end{array}$} & \multicolumn{8}{|c|}{ Intervencije } \\
\hline & & & a & b & c & d & e & f & g & $\mathbf{h}$ \\
\hline $\mathrm{Da}$ & 34 & 11 & 18 & 23 & 15 & 25 & 2 & 8 & 0 & 13 \\
\hline $\mathrm{Ne}$ & 57 & 80 & 9 & 5 & 6 & 72 & 9 & 3 & 10 & 8 \\
\hline $\begin{array}{l}\text { Nema } \\
\text { podataka }\end{array}$ & 9 & 5 & 73 & 72 & 79 & 3 & 89 & 89 & 90 & 79 \\
\hline Ukupno & 100 & 100 & 100 & 100 & 100 & 100 & 100 & 100 & 100 & 100 \\
\hline
\end{tabular}

Legenda: a=intervencije povezane $s$ invaliditetom korisnika, $b=i z v i d i$ obitelji, $c=$ materijalna pomoć obitelji, $\mathrm{d}=$ razvod braka, e=žurna zaštita djeteta bez odgovarajuće roditeljske skrbi/zlostavljanje, zanemarivanje djece, $\mathrm{f}=$ poremećeni odnosi u obitelji, $\mathrm{g}=$ lišenje prava na roditeljsku skrb, $\mathrm{h}=\mathrm{drugo}$

Trećina počinitelja (34\%) ima evidentirano ranije činjenje kaznenih djela, a ranije kazneno djelo ubojstva svaki 9. počinitelj (11\%). Ranije se liječilo u psihijatrijskim bolnicama $37 \%$ počinitelja, u prosjeku 4 puta $(M=3,91 ; S D=3,728)$, najčešće zbog shizofrenije (18\%). Samo 8\% uzorka liječilo se zbog alkoholizma.

Tablica 12. Klasifikacija kaznenog djela, broj žrtava i srodstvo sa žrtvom ( $N=100)$

\begin{tabular}{lccccc}
\hline $\begin{array}{l}\text { Klasifikacija kaznenog djela } \\
(\mathbf{N}=\%)\end{array}$ & \multicolumn{2}{c}{ Broj žrtava (N = \%) } & \multicolumn{2}{c}{ Srodstvo sa žrtvom (N = \%) } \\
\hline Ubojstvo & 36 & Jedna & 86 & Unutar obitelji & 43 \\
\hline Ubojstvo u pokušaju & 42 & Dvije & 7 & Izvan obitelji & 57 \\
\hline Privilegirano ubojstvo & 4 & Više & 7 & Ukupno & 100 \\
\hline Teško ubojstvo & 18 & Ukupno & 100 & & \\
\hline Ukupno & 100 & & & & \\
\hline
\end{tabular}

Većina ubojstava klasificirana je kao osnovno kazneno djelo (36\%), a 43\% počinjeno je protiv člana obitelji (Tablica 12.). Većina ubojstava su jednostruka (86\%).

Tablica 13. Povezanost počinitelja i žrtve te spol žrtava $(N=100)$

\begin{tabular}{lclc}
\hline $\begin{array}{c}\text { Povezanost počinitelja i } \\
\text { žrtve }\end{array}$ & $\begin{array}{c}\text { Prva žrtva } \\
(\mathbf{N}=\%)\end{array}$ & \multicolumn{1}{c}{ Spol žrtve } & Prva žrtva (N = \%) \\
\hline Član uže obitelji & 37 & Muško & 64 \\
\hline Član šire obitelji & 6 & Žensko & 36 \\
\hline Poznanik & 45 & Nema podataka & - \\
\hline Nepoznata osoba & 6 & Ukupno & 100 \\
\hline Drugo & 6 & & \\
\hline Ukupno & 100 & & \\
\hline
\end{tabular}


Najmlađa žrtva imala je nepunu godinu, a najstarija 84 godine. Kao prve žrtve podjednako su zastupljeni poznanici (45\%) i članovi obitelji (43\%, Tablica 13.). Dvije trećine žrtava su muškog spola (64\%), u prosječnoj dobi od 47 godina ( $M=47,06$; $S D=20,193)$. Dobiveni rezultati također ukazuju na niži udio sudioništva kod kaznenog djela ubojstva, koje je prisutno kod tek 13\% počinitelja.

Tablica 14. Način, mjesto i vrijeme počinjenih kaznenih djela i alkoholiziranost u trenutku počinjenja $(\mathrm{N}=100)$

\begin{tabular}{lclc}
\hline Mjesto počinjenja djela & $\mathbf{N}=\%$ & Način izvršenja djela & $\mathbf{N}=\%$ \\
\hline Kuća/stan & 31 & Vlastita fizička snaga & 16 \\
\hline Tuđa kuća/stan & 17 & Vatreno oružje & 25 \\
\hline Ulica & 11 & Hladno oružje & 44 \\
\hline Ugostiteljski objekt & 8 & Drugo & 14 \\
\hline Drugo & 33 & Nema podataka & 1 \\
\hline Ukupno & 100 & Ukupno & 100 \\
\hline Vrijeme počinjenja djela & $\mathbf{N}=\%$ & Alkoholiziranost tempore criminis & $\mathbf{N}=\%$ \\
\hline $00-03$ & 19 & Počinitelj & 29 \\
\hline $04-07$ & 3 & Žrtva & 4 \\
\hline $08-11$ & 11 & Oboje & 21 \\
\hline $12-15$ & 11 & Nitko & 46 \\
\hline $16-19$ & 24 & Ukupno & 100 \\
\hline $20-23$ & 27 & & \\
\cline { 1 - 2 } Nema podataka & 5 & & \\
\cline { 1 - 2 } Ukupno & 100 & &
\end{tabular}

Ubojstvo se najčešće čini hladnim oružjem (44\%), najčešće nožem (30\%). Nešto manje od trećine ubojstava (31\%) počinjeno je u kući, odnosno stanu počinitelja, a između 16 i 23 sata počinjeno je preko polovine (51\%) ubojstava. Polovina počinitelja (50\%) i četvrtina žrtava (25\%) bili su u alkoholiziranom stanju (Tablica 14.). Kod ubojstva koje su počinile osobe s dijagnozom alkoholizma $35 \%$ žrtava bilo je alkoholizirano u trenutku počinjenja kaznenog djela, kod akutno intoksiciranih počinitelja 40\%, a kod trijeznih počinitelja 8\% žrtava. Nadalje, 21\% počinitelja je prema dostupnim podacima bilo izazvano od strane žrtve, pri čemu je taj postotak za trijezne počinitelje iznosio $12 \%$, za akutno intoksicirane $33,3 \%$, a za one s dijagnozom alkoholizma 25,0\%. 
Tablica 15. Motiv za počinjenje kaznenog djela $(\mathrm{N}=100)$

\begin{tabular}{lc}
\hline Osnovni motiv & $\mathbf{N}=\%$ \\
\hline Bračne razmirice & 3 \\
\hline Druge obiteljske razmirice & 12 \\
\hline Ljubomora & 9 \\
\hline Razmirice zbog novca, imovine & 8 \\
\hline Prepirka iz drugih razloga & 20 \\
\hline Netrpeljivost (rasna, nacionalna, vjerska) & 2 \\
\hline Osveta & 1 \\
\hline Koristoljublje & 7 \\
\hline Drugo & 24 \\
\hline Nema podataka & 14 \\
\hline Ukupno & 100 \\
\hline
\end{tabular}

Najčešći motiv (Tablica 15.) je prepirka (20\%), a zatim bračne i druge obiteljske prepirke (15\%), ljubomora (9\%), razmirice zbog novca i imovine (8\%) te koristoljublje (7\%).

\section{Obilježja počinitelja ubojstva prema varijablama kaznenog djela}

Za varijable vezane uz počinjenje kaznenog djela podaci su većinom dostupni, no zanimljivo je da za čak $9 \%$ nedostaje podatak o prethodnom činjenju kaznenih djela (Tablica 16.). Među alkoholičarima najveći je udio (45\%) onih koji su ranije kažnjavani za počinjenje različitih kaznenih djela.

Tablica 16. Povijest činjenja kaznenih djela s obzirom na psihofizičko stanje počinitelja u trenutku počinjenja kaznenog djela $(\mathrm{N}=100)$

\begin{tabular}{lcccc}
\hline & $\begin{array}{c}\text { Trijezno } \\
\text { stanje N (\%) }\end{array}$ & $\begin{array}{c}\text { Akutno opito } \\
\text { stanje N (\%) }\end{array}$ & $\begin{array}{c}\text { Dijagnoza } \\
\text { alkoholizma } \\
\mathbf{N}(\%)\end{array}$ & $\begin{array}{c}\text { Cijeli uzorak } \\
\text { (N = \%) }\end{array}$ \\
\hline Ranije počinili KD & $15(30,0)$ & $10(33,3)$ & $9(45,0)$ & 34 \\
\hline Bez evidentiranih KD & $32(64,0)$ & $16(53,3)$ & $9(45,0)$ & 57 \\
\hline Nema podataka & $3(6,0)$ & $4(13,3)$ & $2(10,0)$ & 9 \\
\hline Ukupno & $50(100,0)$ & $30(100,0)$ & $20(100,0)$ & 100 \\
\hline
\end{tabular}

U Tablici 17. prikazani su podaci o ranijem psihijatrijskom liječenju. Više od polovice trijeznih počinitelja (54\%) ranije je liječeno zbog određenih psihičkih bolesti. 
Tablica 17. Povijest liječenja od psihičkih bolesti s obzirom na psihofizičko stanje počinitelja u trenutku počinjenja kaznenog djela $(N=100)$

\begin{tabular}{lcccc}
\hline $\begin{array}{l}\text { Povijest } \\
\text { liječenja od } \\
\text { psihičkih bolesti }\end{array}$ & $\begin{array}{c}\text { Trijezno stanje } \\
\mathbf{N}(\%)\end{array}$ & $\begin{array}{c}\text { Akutno opito } \\
\text { stanje } \mathbf{N}(\%)\end{array}$ & $\begin{array}{c}\text { Dijagnoza } \\
\text { alkoholizma } \\
\mathbf{N}(\%)\end{array}$ & $\begin{array}{c}\text { Cijeli uzorak } \\
\text { (N = \%) }\end{array}$ \\
\hline $\mathrm{Da}$ & $27(54,0)$ & $7(23,3)$ & $3(15,0)$ & 37 \\
\hline $\mathrm{Ne}$ & $22(44,0)$ & $23(76,7)$ & $16(80,0)$ & 61 \\
\hline Nema podataka & $1(2,0)$ & - & $1(5,0)$ & 2 \\
\hline Ukupno & $50(100,0)$ & $30(100,0)$ & $20(100,0)$ & 100 \\
\hline
\end{tabular}

$\mathrm{U}$ uzorku osobe s dijagnozom alkoholizma nisu evidentirane kao počinitelji kaznenog djela teškog ubojstva (Tablica 18.) i jedina su skupina počinitelja kod koje ima više ubojstava u pokušaju nego dovršenih (55\%).

Tablica 18. Klasifikacija počinjenog kaznenog djela s obzirom na psihofizičko stanje počinitelja u trenutku počinjenja kaznenog djela

\begin{tabular}{lcccc}
\hline & $\begin{array}{c}\text { Trijezno } \\
\text { stanje N (\%) }\end{array}$ & $\begin{array}{c}\text { Akutno opito } \\
\text { stanje N (\%) }\end{array}$ & $\begin{array}{c}\text { Dijagnoza } \\
\text { alkoholizma } \\
\mathbf{N}(\%)\end{array}$ & $\begin{array}{c}\text { Cijeli uzorak } \\
\text { (N = \%) }\end{array}$ \\
\hline Ubojstvo u pokušaju & $19(38,0)$ & $12(40,0)$ & $11(55,0)$ & 42 \\
\hline Ubojstvo na mah & $3(6,0)$ & $1(3,3)$ & - & 4 \\
\hline Ubojstvo & $16(32,0)$ & $11(36,7)$ & $9(45,0)$ & 36 \\
\hline Teško ubojstvo & $12(24,0)$ & $6(20,0)$ & - & 18 \\
\hline Ukupno & $50(100,0)$ & $30(100,0)$ & $20(100,0)$ & 100 \\
\hline
\end{tabular}

Osobe s dijagnozom alkoholizma u većem udjelu čine ubojstvo unutar obitelji (55\%), a akutno opite i trijezne osobe češće čine ubojstva izvan obitelji (63,3\%; $58 \%)$.

Tablica 19. Počinjenje kaznenog djela unutar i izvan obitelji s obzirom na psihofizičko stanje počinitelja u trenutku počinjenja kaznenog djela

\begin{tabular}{lcccc}
\hline & $\begin{array}{c}\text { Trijezno stanje } \\
\mathbf{N}(\%)\end{array}$ & $\begin{array}{c}\text { Akutno opito } \\
\text { stanje N (\%) }\end{array}$ & $\begin{array}{c}\text { Dijagnoza } \\
\text { alkoholizma } \\
\mathbf{N}(\%)\end{array}$ & $\begin{array}{c}\text { Cijeli uzorak } \\
\text { (N = \%) }\end{array}$ \\
\hline $\begin{array}{l}\text { Ubojstvo izvan } \\
\text { obitelji }\end{array}$ & $29(58,0)$ & $19(63,3)$ & $9(45,0)$ & 57 \\
\hline $\begin{array}{l}\text { Ubojstvo unutar } \\
\text { obitelji }\end{array}$ & $21(42,0)$ & $11(36,7)$ & $11(55,0)$ & 33 \\
\hline Ukupno & $50(100,0)$ & $30(100,0)$ & $20(100,0)$ & 100 \\
\hline
\end{tabular}


RASPRAVA

U ovom istraživanju korišteni su podaci osoba koje su počinile kazneno djelo ubojstva ili pokušaja ubojstva, pri čemu je $50 \%$ počinitelja bilo trijezno u trenutku počinjenja djela, dok je preostalih $50 \%$ bilo alkoholizirano. Od toga je 20 bilo ovisnika o alkoholu, a 30 akutno intoksiciranih. Goreta, Peko-Čović i Buzina (2004.) navode kako, za razliku od kriterija za ovisnost o alkoholu, kriteriji za zloupotrebu ne uključuju toleranciju ni obrazac prisilnog uzimanja alkohola, već sadrže samo štetne posljedice ponovnog uzimanja, poput zatajivanja u socijalnom funkcioniranju te ponovljenih problema sa zakonom. Zbog toga su te dvije skupine počinitelja proučavane odvojeno, što je dovelo do malog broja podataka po pojedinoj skupini te, uzevši u obzir i velik broj podataka koje nedostaju na pojedinim varijablama, rezultate treba promatrati u okviru tih ograničenja.

Istraživanje je pokazalo da ubojstvo čine sve dobne skupine te da su i žrtve svih dobnih skupina. Prema Žarković Palijan i sur. (2009.), kada su »društveni potrošači alkoholnih pića« počinitelji kaznenog djela ubojstva, najčešće se radi o osobama u dobi od 30 do 50 godina. Dundović (2008.), s druge strane, sugerira kako su počinitelji ovisnici o alkoholu osobe starije dobi (od 50 do 60 godina). Rezultati ovog istraživanja u skladu su s takvim nalazima.

Među počiniteljima alkoholičarima najveći je udio onih u partnerskim zajednicama (50\%). U prilog tome može se spomenuti i istraživanje Koludrovića (1989.) u kojem se nalazi kako je kod alkoholičara stopa očuvanih obitelji najviša, ali je najlošije obiteljsko ozračje. S druge strane, osobe koje su kazneno djelo počinile u trijeznom stanju najčešće se ne nalaze u partnerskom odnosu (njih 76\%) te najčešće nikada nisu ni sklapale nikakvu bračnu zajednicu (62\%). Tradicionalna kriminologija ubojstvo tretira kao ruralni delikt ili, s druge strane, delikt visoko urbanih sredina (Meter Celinščar i Kovčo Vukadin, 2002.). Usmjeravajući se na prebivalište počinitelja kaznenog djela ubojstva, može se vidjeti kako počinitelji alkoholičari u većem broju slučajeva žive na selu (60\%), za razliku od ostale dvije skupine koje najčešće žive u manjem gradu. Što se socioekonomskog statusa tiče, počinitelji s dijagnozom alkoholizma u velikom postotku imaju nepovoljan socioekonomski status (60\%). S druge strane, počinitelji koji su djelo počinili u akutno opitom stanju uglavnom imaju prosječan, to jest osrednji socioekonomski status, kao i druga skupina počinitelja koji su djelo počinili u trijeznom stanju. Važno je napomenuti kako, za razliku od alkoholičara počinitelja ubojstva, u preostale dvije skupine barem jedan dio njih ima vrlo dobar socioekonomski status. Moguće je pretpostaviti kako će osobe lošeg socioekonomskog statusa prije razviti bolest alkoholizma, ali $\mathrm{i}$, s druge strane, da će alkoholizam nekoga dovesti u situaciju lošeg socioekonomskog statusa. Osobe niskog socioekonomskog statusa teško mogu promijeniti svoj 
status, više su opterećene raznim konfliktnim situacijama, nezaposlene su ili obavljaju teške fizičke poslove, te se i teže nose s problemima i frustracijama, s obzirom da nemaju dovoljno mogućnosti i sredstava da poboljšaju životne uvjete. Singer i Uzelac (2005.) zagovaraju ovu tezu te smatraju kako neke osobe lošeg socioekonomskog statusa svoje frustracije mogu rješavati upuštanjem u različita devijantna ponašanja te bijegom u alkoholizam i kriminalno ponašanje. $S$ druge strane, učestala konzumacija alkohola velik je financijski trošak, koji za sobom povlači i niz drugih problema, poput većeg rizika za gubitak posla, što osobu može dovesti u situaciju u kojoj se njen socioekonomski status pogoršava. Također, u obzir treba uzeti i obiteljsko okruženje u kojem je pojedinac odrastao, koje u određenim situacijama može dovesti do povećanog rizika za razvoj alkoholizma, ali i do manjih mogućnosti za obrazovanje i nalaženje adekvatnog zaposlenja, a time i nižeg socioekonomskog statusa.

Tako se kod svih triju skupina ističu narušeni obiteljski odnosi u primarnoj obitelji, a čak dvije trećine počinitelja nije u partnerskom odnosu, odnosno nikada nisu sklapali bračnu zajednicu, udovci su ili su se razveli. Probleme tijekom školovanja iskazuje većina počinitelja ubojstava, jednako kao i društveno neprihvatljivo ponašanje poput bjegova iz škole, kuće, te ranu zloupotrebu alkohola. lako je većina počinitelja iz svih ispitanih kategorija odrastala u potpunim obiteljima, to im nije pomoglo da se razviju u stabilne ličnosti jer je većina njih za koje su podaci bili dostupni svakodnevno bila izložena neadevaktnim obrascima ponašanja, poput nasilja, psihičkog i fizičkog, zanemarivanja i alkoholizma roditelja. Sukladno teoriji socijalnog učenja, djeca pamte i uče na primjeru svojih roditelja, te naučeno povezuju sa situacijama kada odrastu u kojima se nađu. Ako nisu imali od koga naučiti drugačije odgovarati na probleme, dolazi do transgeneracijskog prijenosa nasilja (Kozarić Kovačić, Grubišić-llić i Grozdanić, 2005.). Kovčo (1997.) zaključuje da razvoj djeteta bez roditelja ili bez jednog roditelja nema značajan utjecaj na samu osobu. Smatra kako veći i negativniji utjecaj ima odrastanje u potpunoj obitelji u kojoj su odnosi između roditelja neskladni i nasilni. Navedeno se može primijeniti i na rezultate ovog istraživanja. Upadljivo je da su alkoholičari počinitelji ubojstva odrastali u znatno negativnijem obiteljskom okruženju. Svaki peti odrastao je uz oba roditelja alkoholičara, odnosno dvije trećine imalo je oca alkoholičara. Otac alkoholičar često je prisutan i kod $40 \%$ akutno intoksiciranih počinitelja. Kod te dvije skupine u većem je udjelu prisutno i konzumiranje alkohola za vrijeme osnovnoškolskog obrazovanja. Navedeno se također može objasniti teorijom socijalnog učenja, odnosno činjenicom da je velik broj tih osoba odrastao u obiteljima gdje je konzumacija alkohola bila učestala i prekomjerna. Nadalje, moguće je i da su bili izloženi neadekvatnim roditeljskim postupcima te da su tijekom odrastanja imali manje prilika za poboljšanje materijalnog statusa, čime se može objasniti i ranije

\section{6 članci}


spomenuti niži socioekonomski status počinitelja s dijagnozom alkoholizma. Velik broj podataka o ranom razvoju i iskustvima u primarnoj obitelji nije dostupan, što ne samo da predstavlja problem za donošenje zaključaka o prikazanim rezultatima, već je i velik nedostatak u praksi. Naime, kako je poznato da su obiteljske varijable značajan rizični čimbenik, poznavanje obiteljskih okolnosti može pomoći stručnjacima koji rade s počiniteljima u razumijevanju njihove situacije te adekvatnom planiranju terapijskih intervencija.

$\mathrm{U}$ istraživanje je uključena i varijabla ranijih intervencija u okviru sustava socijalne skrbi, kako u primarnoj obitelji počinitelja, tako i u sadašnjoj. Navedena varijabla uključena je iz razloga kako bi se promotrio još jedan mogući aspekt vezan uz počinjenje kaznenog djela. Naime, korisnici socijalne skrbi oduvijek su, bilo da su u sustavu socijalne skrbi zbog razvoda braka, materijalne pomoći, narušenih obiteljskih odnosa, problema vezanih uz invaliditet ili nasilničko ponašanje, stigmatizirani i stavljani na margine društva. Takve situacije smanjuju životne šanse pojedinca te mogu dovesti do sukoba u obitelji. Na osobnom planu povezane su s narušenom slikom o sebi, smanjenim samopouzdanjem te sniženim pragom tolerancije na frustracije (Petak, 2005.). Veoma je indikativno što za većinu počinitelja nije bilo podataka o tome jesu li u njihovim obiteljima ikada provedene intervencije socijalne skrbi. Navedeni podatak sugerira da još uvijek ne postoji dovoljno jasna prepoznatljivost važnosti uloge socijalnog rada u obitelji.

Kao što je bilo važno ispitati varijable intervencija socijalne skrbi, tako je bilo važno ispitati i eventualna liječenja od ovisnosti o alkoholu, odnosno liječenja od raznih psihičkih bolesti. Posljedice dugotrajne konzumacije alkoholnih pića i alkoholizma mogu biti različite, kao na primjer komplikacije na psihičkom, tjelesnom i socijalnom planu u vidu oštećenja jetre, karakteroloških promjena, oštećenja i disfunkcije mozga, početne deterioracije intelektualnih funkcija, promjena ličnosti, sve do psihoorganskog sindroma. Navedeno može predstavljati izvjesne prediktore za počinjenje kaznenog djela ubojstva. Među počiniteljima kaznenog djela ubojstva, njih $37 \%$ liječeno je u psihijatrijskim bolnicama, u prosjeku 4 puta. Najčešće dijagnoze koje se pojavljuju u navedenom uzorku su u okviru shizofrenije (18\%), a samo $8 \%$ počinitelja liječilo od ovisnosti o alkoholu. Također, i Mužinić Masle i Goreta (2000.) kao najčešće razloge za prijašnje hospitalizacije navode ovisnost $(8,6 \%)$ i shizofreniju $(7,1 \%)$. Kovačević (2008.) napominje kako su počinitelji s dijagnozom shizofrenije zastupljeniji u skupini počinitelja koji ne piju ili piju umjereno. Nizak postotak ranije liječenih zbog konzumacije alkohola sugerira da potreba za liječenjem često nije prepoznata u društvu i okolini te tek počinjenje ubojstva dovodi do medicinske skrbi za alkoholičare.

U većini slučajeva kod ubojstva u pokušaju postoji namjera za dovršavanjem djela, no počinitelj ju ne uspijeva ostvariti zbog različitih faktora na koje ne može 
utjecati, poput brzog reagiranje hitne medicinske pomoći. U ovom istraživanju pokazalo se da trijezni počinitelji u najvećem udjelu dovršavaju ubojstvo (62\%), što se dijelom može objasniti njihovom većom fizičkom sposobnošću, koja nije smanjena uslijed konzumacije alkohola, u trenutku počinjenja. Dobiveni rezultati u skladu su s istraživanjem Dundovića (2008.) koji navodi da trijezni počinitelji u najvećem broju slučajeva $(83,8 \%)$ dovršavaju ubojstvo. Prema prikazanim rezultatima, niti jedan alkoholičar nije počinio teško ili ubojstvo na mah. Rezultati potvrđuju Dundovićevu (2008.) tvrdnju kako počinitelji alkoholičari, češće od »društvenih potrošača« $i$ osoba koje ne piju, čine »obično « ubojstvo, dok »društveni potrošači« i osobe koje ne piju češće čine kvalificirana i teška ubojstva.

Alkoholičari u najvećem udjelu čine ubojstvo u obitelji, a najčešće su u pitanju članovi uže obitelji poput supruge/izvanbračne supruge (20\%), sina (15\%) i brata (15\%). Budući da se ličnost mijenja s razvojem alkoholizma, moguće je pretpostaviti kako će prve žrtve alkoholičara biti članovi obitelji, koji su uz njih od samih početaka dok je konzumacija alkohola još bila na razini »društvene potrošnje.« $\mathrm{S}$ razvojem alkoholizma u obitelji rastu i tenzije, osoba se sve slabije kontrolira, odgovara neadekvatno na frustracije te sve svoje frustracije i agresiju usmjerava prema članovima obitelji, prvenstveno supruzi, a potom i djeci. Bračne nesuglasice postaju sve češće, s obzirom da i financijska situacija obitelji postaje sve lošija. Navedeno je prvenstveno odraz već lošeg socioekonomskog statusa alkoholičara, što je već ranije spomenuto, koji postaje sve lošiji učestalim trošenjem novčanih sredstava na svakodnevnu kupnju alkoholnih pića i manjom mogućnošću zarade. Agresija se može manifestirati kroz psihičko i fizičko nasilje, koje učestalim ponavljanjem može imati i fatalne ishode. Alkoholičaru je, zbog sniženog praga tolerancije na frustracije, i najmanja sitnica dovoljna da »plane« i da reagira na način, na koji vjerojatno, da je trijezan i da na trenutak razmisli o svojim postupcima, ne bi reagirao. S druge strane, ubojstva u kojima ne postoji odnos između počinitelja i žrtve izrazito su rijetka (6\%). Navedeno potvrđuje rezultate Ramljaka (2007.) koji navodi da je, prema brojnim istraživanjima, minimalna incidencija nepoznatih počinitelja i žrtve te kako ona iznosi između 5\% i 9\%.

I alkoholiziranost žrtve u trenutku počinjenja ubojstva može utjecati na njezinu viktimizaciju na različite načine, na primjer provociranjem, vrijeđanjem, izazivanjem počinitelja. U ovom istraživanju bilo je alkoholizirano $25 \%$ žrtava. Relativno velik broj žrtava kaznenih djela koja su počinile osobe s dijagnozom alkoholizma (35\%) i akutno intoksicirane osobe (40\%) bio je u trenutku počinjenja pod utjecajem alkohola. Kako se inhibicije smanjuju kod počinitelja u alkoholiziranom stanju, isto se događa i sa žrtvom. Također se smanjuje strah te žrtva, kao i počinitelj, dobiva osjećaj lažne hrabrosti, što može dovesti do fatalnog ishoda. Chan i Payne (2013.) u svom radu o ubojstvima u Australiji prikazuju da je u vrijeme počinjenja

\section{8 članci}


kaznenog djela ubojstva 37\% počinitelja i 35\% žrtava bilo pod utjecajem alkohola. S alkoholiziranošću žrtve tempore criminis povezuje se i izazvanost počinitelja. Prema dobivenim podacima, $79 \%$ počinitelja nije bilo izazvano, no kada se podaci pogledaju prema pojedinim skupinama, u većem su udjelu izazivani počinitelji koji su djelo počinili u akutno opitom stanju $(33,3 \%)$ te počinitelji s dijagnozom alkoholizma $(25,0)$.

Analiza sredstava počinjenja kaznenog djela ubojstva, pokazala je kako počinitelji djelo najčešće čine hladnim oružjem (44\%), od čega najveći postotak odlazi na nož (30\%). Vatreno oružje zastupljeno je u četvrtini, a vlastita fizička snaga zastupljena u svakom šestom slučaju. Dobiveni rezultati u skladu su s rezultatima Chana i Payna (2013.) koji kao najčešći uzrok ubojstva u Australiji navode ubodne rane (39\%). Navedene rezultate moguće je objasniti činjenicom kako je hladno oružje svim dobnim skupinama počinitelja najdostupnije jer se često koristi u obiteljskim domaćinstvima, posebice u ruralnim dijelovima, gdje je i velik broj ubojstva počinjen. Skoro polovina ubojstva dogodila se u kući/stanu počinitelja ili žrtve, a samo $8 \%$ u ugostiteljskom objektu. Za razliku od navedenih rezultata, Mužinić Masle, Goreta i Jukić (2000.) navode da je najviše ubojstava (34,3\%) počinjeno na otvorenim prostorima. Najviše ubojstava dogodilo se u poslijepodnevnim i večernjim satima, odnosno preko polovine ubojstava počinjeno je između 16 i 23 sata.

Analizirajući motive počinjenja kaznenog djela ubojstva, dolazi se do zaključka kako se u svakom pojedinom slučaju može pronaći više međusobno povezanih motiva. Ljubomora dovodi do bračnih razmirica, koje zatim mogu rezultirati ubojstvom iz osvete. Prema Mužinić (2009.), alkohol može smanjivati muškarčeve inhibicije, uzrokujući pokazivanje sumnje koje kod njega već postoji. Također, muškarci koji su zabrinuti za svoj brak, mogu početi prekomjerno konzumirati alkoholna pića. Alkohol također može utjecati na razvoj ljubomore i sumnje, a koje ranije nisu postojale, uz nastajanje krivih percepcija, distorzija, poteškoća u interpretaciji stvari (Mužinić, 2009.). Kako bi se što točnije odredio motiv kaznenog djela, svako kazneno djelo nužno je promatrati zasebno, zbog kompleksnosti, prvenstveno odnosa između počinitelja i žrtve i njihove povijesti. Kao najčešći motiv u ovom istraživanju ističe se prepirka iz različitih razloga (20\%), zatim bračne i druge obiteljske prepirke (15\%), ljubomora (9\%), razmirice zbog novca i imovine (8\%) te koristoljublje (7\%). Vidljivo je da su motivi za počinjeno ubojstvo raznovrsni, no najveći dio njih može se povezati s ranije spomenutim problemima u obiteljskim odnosima i lošim socioekonomskim prilikama. Ipak, nužno je promatrati svaki slučaj zasebno, prvenstveno zbog kompleksnosti situacija i međuodnosa između počinitelja i žrtve. Iza svakog ubojstva i poznatog motiva stoji još nešto u pozadini. Najčešće je riječ o kombinaciji različitih motiva u kojima je konzumacija alkohola jedan od konstelativnih faktora. 


\section{ZAKLJUČAK}

Analiza podataka o počiniteljima ubojstva u skladu je s profilima počinitelja iz literature, posebice onih s dijagnozom alkoholizma. Razumijevanje ove problematike važno je za djelovanje struke socijalnog rada, naročito u vidu transgeneracijskog prijenosa nasilnog ponašanja, koje može biti pojačano prisutnošću alkoholizma. Osim rada s počiniteljima fatalnih delikata uzrokovanih alkoholizmom, treba raditi i s članovima obitelji, prvenstveno djecom, kako bi se krug nasilja prekinuo. Nužno je stvaranje preventivnih i tretmanskih programa unutar struke socijalnog rada, posebice kroz interdisciplinarnu suradnju, čime bi se prevenirala nova kaznena djela, ponajviše ona uzrokovana alkoholizmom i konzumacijom alkohola. Značajan nalaz ovog istraživanja je i činjenica da pojedini podaci o počiniteljima nisu dostupni u okviru sudsko-psihijatrijskih ekspertiza. Prvenstveno se radi o podacima o ranom razvoju i iskustvima u primarnoj obitelji te o ranijim intervencijama u okviru sustava socijalne skrbi. Navedeni podaci nisu značajni samo za prikupljanje statistika i provođenje istraživanja, već mogu imati i važne implikacije za praksu, od preporuka stručnjaka vezano uz odluke o kaznama do planiranja adekvatnog tretmana počinitelja.

\section{LITERATURA}

1. Chan, A. \& Payne, J. (2013). Homicide in Australia 2008-09 to 2009-10 - national homicide program - Annuaeport. Canberra: Australian Institute of Criminology.

2. Dearden, J. \& Payne, J. (2009). Alcohol and homicide in Australia. Australian Institute of Criminology, 372, 1-6.

3. Dundović, D. (2005). Razlike u nekim socioekonomskim, fenomenološkim i penološkim obilježjima počinitelja ubojstva intimnih partnera s obzirom na spol počinitelja. Magistarski rad. Zagreb: Edukacijsko-rehabilitacijski fakultet.

4. Dundović, D. (2008). Ubojstva intimnih partnera i alkohol. Hrvatski ljetopis za kazneno pravo i praksu, 15 (1), 177-203.

5. Džaja-Hajduk, D. (2003). Usporedna analiza kriminološko - forenzičkih značajki alkoholičara i shizofrenih bolesnika počinitelja nasilničkih delikata. Kriminologija i socijalna integracija, 11 (1), 85-92.

6. Flanagan, R. \& Fisher, D. (2008). Volatile substance abuse and crime: Data from UK press cuttings 1996-2007. Medicine, Science and the Law, 48 (4), 295-306.

7. Goreta, M., Peko-Čović, I. \& Buzina, N. (2004). Psihijatrijska vještačenja. Zbirka ekspertiza - knjiga prva. Kazneno pravo. Zagreb: Naklada Zadro. 
M. Draganić, D. Kovačević, L. Mužinić, N. Sušac: Alkohol kao kriminogeni čimbenik ...

8. Kaminer, Y. \& Bukstein, O. G. (2008). Adolescent substance abuse: Psychiatric comorbidity and high risk behaviours. New York: Routledge.

9. Koludrović, M. (1989). Forenzičko psihijatrijsko prosuđivanje afektivnih čina kod počinitelja krivičnih djela ubojstva. Doktorska disertacija. Zagreb: Medicinski fakultet.

10. Koludrović, M. (2010). Neki forenzičko psihijatrijski problemi akutno napitog stanja i alkoholizma. U: Žarković Palijan, T. \& Kovačević, D. (ur.), Iz forenzičke psihijatrije. Zagreb: Ceres, 119-145.

11. Kovačević, D. (2008). Psihosocijalni i sociodemografski aspekti ubojstva u obitelji. Doktorska disertacija. Doktorska disertacija. Zagreb: Sveučilište u Zagrebu, Pravni fakultet, Studijski centar socijalnog rada.

12. Kovčo, I. (1997). Razlike u nekim socio-ekonomskim, fenomenološkim i penološkim obilježjima počinitelja kaznenog djela ubojstva različitog spola. Doktorska disertacija Zagreb: Fakultet za defektologiju.

13. Kozarić-Kovačić, D. (1996). Alkoholičari počinitelji kaznenih djela protiv života i tijela. Zagreb: Policijska akademija - MUP RH.

14. Kozarić-Kovačić, D., Grubišić-Ilić, M. \& Grozdanić, V. (2005). Forenzička psihijatrija (drugo izdanje). Zagreb: Medicinska naklada.

15. Kozarić-Kovačić, D., Nenadić-Šviglin, K. \& Ljubin, T. (1996). Sociopatološka obilježja narkomana i osoba s poremećajima ličnosti - počinitelja kaznenih djela. Zagreb: Policijska akademija - MUP RH.

16. Nađ, I. (2001). Obiteljska ubojstva u Republici Hrvatskoj. Magistarski rad. Zagreb: Visoka policijska škola.

17. Meter Celinšćak, A. \& Kovčo Vukadin, I. (2002). Ubojstva s obzirom na agresivnost počiniteljica. Policija i sigurnost, 12 (1-3), 1-21.

18. Mužinić, L. (2009). Forenzično psihijatrijska obilježja ljubomore. U: Žarković Palijan, T. \& Kovačević, D. (ur.), Iz forenzičke psihijatrije 3, Kutina: Matica Hrvatska, 283-294.

19. Mužinić Masle, L. \& Goreta, M. (2000). Alkohol kao kriminogeni čimbenik kod počinitelja kaznenog djela ubojstva i pokušaja ubojstva. Socijalna psihijatrija, 28 (1), 29-33.

20. Mužinić Masle, L., Goreta, M. \& Jukić, V. (2000). The comparison of forensic-psychiatric traits between female and male perpetrators of murder and attempted murder. Collegium Antropologicum, 24 (1), 91-99.

21. Petak, O. (2005). Aktivnost centra za socijalnu skrb u radu sa zlostavljanom i zapuštenom djecom. U: Singer, M. \& sur. (ur.), Kriminologija delikata nasilja Nasilje nad djecom i ženama, maloljetničko nasilje. Zagreb: Nakladni zavod Globus, 180-240.

22. Ramljak, A. A. (2007). Kriminološke i viktimološke determinante u aktu ubistva, Godišnjak pravnog fakulteta u Banja Luci, 99-118. 
23. Singer, M. \& Uzelac, S. (2005). Kriminološke osobitosti zapuštanja i zlostavljanja djece i maloljetnika. U: Singer, M. \& sur., Kriminologija delikata nasilja - Nasilje nad djecom i ženama, maloljetničko nasilje. Zagreb: Nakladni zavod Globus, 88-121.

24. Svjetska zdravstvena organizacija (1999). MKB-10 Klasifikacija mentalnih poremećaja i poremećaja ponašanja. Klinički opisi i dijagnostičke smjernice (Deseta revizija). Zagreb: Medicinska naklada.

25. Žarković Palijan, T. (2004). Značajke osobnosti alkoholičara počinitelja i nepočinitelja kaznenih djela. Doktorska disertacija. Zagreb: Sveučilište u Zagrebu, Medicinski fakultet.

26. Žarković Palijan, T., Kovačević, D., Radeljak, S., Kovač, M. \& Mustapić, J. (2009). Forensic aspects of alcohol abuse and homicide. Collegium Antropologicum, 33 (3), 893-897.

27. World Health Organization (2002). World report on violence and health. Preuzeto s: http://whqlibdoc.who.int/publications/2002/9241545615_eng. pdf?ua=1 (10.4.2014.). 
M. Draganić, D. Kovačević, L. Mužinić, N. Sušac: Alkohol kao kriminogeni čimbenik ...

\title{
Mateja Draganić
}

Dražen Kovačević

Neuropsychiatric Hospital Dr.lvan Barbot

University Department for Forensic Science of the University of Split

\section{Lana Mužinić}

Dubrava Clinical Hospital

Department of Psychiatry

\section{Nika Sušac}

University of Zagreb

Faculty of Law

Department of Social Work

\section{ALCOHOL AS CRIMINOGENIC FACTOR IN HOMICIDE AND ATTEMPTED HOMICIDE}

\begin{abstract}
The aim of this research was to study and learn about the characteristics of homicide due to the psychological and physical condition of the perpetrator and characteristics of individual offender. We have investigated the characteristics of the offender with respect to their psychophysical condition, socio-demographic variables, psychosocial characteristics and the characteristics of the crime. We analyzed the terms of alcoholism, acute alcohol intoxication and murder. The study was conducted on the forensic psychiatric expertise at the Institute for Forensic Psychiatry Dr. Ivan Barbot in Popovača on male offenders for homicide and attempted homicide in the Republic of Croatia. The research results show the specifics of the three treatment groups (perpetrators that were acutely intoxicated, offenders with a diagnosis of alcoholism, and the perpetrators which were sober in the time of offense), particularly in terms of variables related to age, marital status, socioeconomic status, history of commission of criminal offenses and number of previous hospitalizations. Results demonstrate that knowledge and understanding of the mentioned issues is important for the profession of social work, and that it can be helpful in daily work, both in prevention and in the work with perpetrators of the murder and their families.
\end{abstract}

Key words: alcohol, alcoholism, homicide. 
